\title{
Meningkatnya Hasil Belajar Agama Islam Setelah Pengunaan Model Make A Match
}

\author{
Sumarni Badewang \\ SMPN 2 Singaraja \\ Email: sumarnibadewang2018@mail.com
}

\begin{abstract}
Abstrak
Tujuan penelitian tindakan keas ini adalah untuk mengetahui adanya peningkatan minat belajar siawa kelas VIII SMP N 2 Singaraja setelah belajar mengunakan model Make A Match. Jenis penelitian dilakukan adalah jenis penilain tindakan kelas yang terdiri atas 2 siklus. Subjek dalam penelitian ini adalah siswa kelas VIII. Objeknyanya adalah siswa kelas VII.12 yang berjumlah 11 orang yang terdiri dari 7 laki-laki dan 4 permpuan. Analisis data yang digunakan adalah Penelitian ini menggunakan analisis diskriptif dengan pengumpulan data dengan observasi,, wawancara dan post-tes. Hasil peneilitain ini menunjukan bahwa adanya peningkatan hasil belajar agama islam ini dari nilai rata-rata dan jumlah siswa yang tuntas dari data awal, sisklus 1 dan siklus 2. Secara berturut-turun ditunjukkan sebagi berikut rata-rata 69,96 siswa tuntas 39,47\% (Data awal),rata-rata hasil belajar 75,83 dan siswa tuntas $65,79 \%$ (siklus I), serta rata-rata hasil belajar 82,70 dan siswa tuntas $89,47 \%$. Dari hasil tersebut dapat dikatakan bahwa model make a match dapat meningkatkan hasil belajar agama islam siswa kelas VIII.12 di SMPN 2 Singaraja.
\end{abstract}

Keywords: Hasil belajar, make a match

\begin{abstract}
The purpose of this basic action research is to find an increase in interest in learning for students of class VIII of SMP N 2 Singaraja after learning to use the Make A Match model. This type of research is a type of class action assessment consisting of 2 cycles. The subjects in this study were students of class VIII. The object is students in class VII.12, totaling 11 people consisting of 7 men and 4 women. Analysis of the data used is this research using descriptive analysis by collecting data by observation, interviews, and post-tests. The results of this study indicate that there is an increase in the Islamic learning outcomes of the average value and the number of students who have completed the preliminary data, cycle 1 and cycle 2. Consecutively shown as follows the average of 69.96 students complete $39.47 \%$ (Preliminary data), the average learning outcomes are 75.83 and students are $65.79 \%$ complete (cycle I), and the average learning outcomes are 82.70 and students are complete $89.47 \%$. From these results it can be said that the make a match model can improve the learning outcomes of Islamic students of class VIII.12 at SMPN 2 Singaraja.
\end{abstract}

\section{Pendahuluan}

Pendidikan dalam arti umum merupakan suatu aktivitas untuk mengembangkan seluruh aspek kepribadian manusia yang berlangsung seumur hidup sesuai dengan nilai-nilai yang ada di dalam masyarakat dan kebudayaan. Lebih spesifik pada pendidikan agama Islam disebutkan bahwa pendidikan Islam merupakan proses transformasi dan internalisasi ilmu pengetahuan dan nilai-nilai pada diri anak didik melalui pertumbuhan dan pengembangan potensi fitrahnya guna mencapai keselarasan dan kesempurnaan hidup dalam segala aspek (Muhaimin Abdul Mudjib: 1993)

Peraturan Pemerintah Nomor 19 Tahun 2005 tentang Standar Nasional Pendidikan pasal 6 ayat (1) menjelaskan bahwa Pendidikan Agama Islam merupakan kelompok mata pelajaran Agama dan akhlak mulia untuk membentuk peserta didik menjadi manusia yang beriman dan bertakwa kepada Tuhan Yang Maha Esa serta berakhlak mulia. Oleh karenya secara subtansi Pendidikan Agama memikul beban yang sangat luas, sebab pendidikan Agama harus menyentuh seluruh aspek kemanusiaan yang ada seperti aspek akal, emosi dan spiritual.

Ini menunjukkan bahwa Pendidikan Agama Islam memiliki posisi yang strategis dalam pengembangan sumber daya manusia di bidang kegaamaan-spiritual, dalam hal ini peserta didik merupakan aset negeri ini. Oleh karena pembelajaran sejatinya berlangsung secara efektif efesien. Harapan ini dapatlah tercapai apabila proses pembelajaran dapat dilaksanakan dengan minat yang tinggi dari peserta didik itu sendiri.

Tanggung jawab peserta didik dalam belajar sangat penting untuk diperhatikan guru karena tanggung jawab itu termasuk motivasi instrisik. Motivasi instrisik ini dapat dipertinggi dengan penggunaan materi yang menarik dan juga cara penyampaian materi pelajaran yang menarik pula. Beberapa pendekatan pembelajaran memiliki orientasi tertentu dengan tujuan akhirnya, seperti penyampaian materi menjadi menarik bagi peserta didik mudah untuk belajar. Selama ini, metodologi pembelajaran agama Islam yang diterapkan masih mempertahankan cara-cara lama (tradisional) seperti ceramah, menghafal dan demonstrasi praktik-praktik ibadah yang tampak gersang. Cara-cara seperti itu diakui atau tidak akan membuat peserta didik bosan, jenuh dan kurang bersemangat dalam belajar agama islam. Jika peserta didik kurang tertarik dengan metode yang digunakan oleh guru, maka dengan sendirinya peserta didik akan memberikan umpan balik (feedback) yang kurang menyenangkan dalam proses pembelajaran, misalnya; peserta didik menjadi tidak simpati tehadap guru 
pelajaran, materi-materi pelajaran dan lama kelamaan bisa menimbulkan sikap acuh tak acuh terhadap pelajaran Agama Islam. Oleh karena itu, penting sekali bagi guru Agama Islam menggunakan model pembelajaran yang lebih kreatif dan inovatif, agar siswa dapat memberikan umpan balik yang positif sehingga akan meningkatkan minat, simpati dan keingintahuan yang mendalam terhadap mata pelajaran Agama Islam.

Pengalaman belajar hanya dapat diperoleh jika siswa berpartisipasi secara aktif. Bentuk belajar secara aktif meliputi interaksi antara guru dengan peserta dididk, peserta dididk dengan peserta dididk lainnya, sekolah dengan rumah, sekolah dengan masyarakat dengan segala macam alat serta media pembelajaran. Dengan demikian, peserta dididk perlu didorong untuk senantiasa berpartisipasi aktif dalam pembelajaran sehingga pengalaman belajar yang mereka dapatkan juga semakin banyak

Demikian pula pengalaman keagamaan hendaknya di pelajari peserta didik melalui pengalaman yang aktual. Beberapa ketrampilan keagamaan dapat mereka pelajari melalui dramatisasi, bermain peran atau diskusi, misalnya: sembahyang, cara makan, cara bersopan santun, adab terhadap orangtua dan sebagainya. Sebagian lagi mungkin menghendaki ketrampilan menggunakan alat-alat dengan cara-cara tertentu, seperti misalnya pada peristiwa penyembelihan kurban, membagikan zakat fitrah dan sebagainya. (Zakiyah Daradjat,1983).

Dari hasil observasi, peneliti mengetahui sejauh mana kemampuan materi yang sudah diajarkan, terutama pada aspek Al-Quran. Untuk mengetahui ini penulis melakukan test kemampuan pada siswa kelas VIII.12 tentang hukum bacaan qalqalah dan ra'. Hasil dari test menunjukkan dari 11 orang peserta rata-rata mendapatkan nilai rata-rata 40 sementara KKMnya 75.

Untuk memberikan pengalaman belajar yang berarti bagi siswa dan menyelesaikan masalah tersebut, guru perlu menggunakan model pembelajaran yang sesuai dengan karakteristik materi yang hendak diajarkan. Salah satu caranya dengan penggunaan model pembelajaran yang tepat. Model pembelajaran sangat penting untuk digunakan sebagai cara pemecahan masalah selain teknik-teknik, teori-teori, metode-metode tertentu. Penggunaan hal-hal tersebut tentu tidak boleh dilakukan tanpa landasan teori yang benar. Pengertian tersebut didukung oleh cuplikan pendapat ahli. Selanjutnya yang sangat penting adalah mengetahui tindakan pembelajaran apa yang dilakukan guru. Tindakan tersebut berupa penggunaan metode pembelajaran baru, yang diyakini (berdasarkan teori) lebih baik dari metode pembelajara yang selama ini yang telah dilakukan (Suhardjono, 2011:17). Salah satu model pembelajaran yang digunakan adalah model make a match.

Model belajar make a match dikembangkan oleh Lorna Curran tahun 1994. Model ini sering juga disebut model mencari pasangan. Dalam teorinya model ini merupakan suatu pembelajaran yang melibatkan orang lain dalam menyelelesaikan persoalan, sehingga hal ini bagian dari sistem pengajaran cooperative learning.

Langkah-langkah yang dapat dilakukan dalam penerapan Model belajar make a match adalah sebagai berikut :(1) Guru memberikan gambaran apa yang harus dilakukan peserta didik dari bahan ajar yang disediakan; (2) Guru menyiapkan beberapa kartu yang berisi beberapa konsep atau topik yang cocok untuk reviwe, sebaiknya satu bagian kartu soal dan bagian lainnya kartu jawaban; (3)Setiap siswa mendapat satu buah kartu; (3) Tiap siswa memikirkan jawaban soal dari kartu yang dipegang; (4) Setiap siswa mencari pasangan yang mempunyai kartu yang cocok dengan kartunya; (5) Setiap siswa yang dapat mencocokan kartunya sebelum batas waktu yang telah ditentukan diberi poin; (6) Masing-masing pasangan yang telah cocok mempesentasikan hasilnya, sementara yang lain memberikan komentar; (7) Peserta yang berhasil dengan pasangannya diberi tepuk tangan atau pujian lainnya; (8) Guru merefleksi dengan menayangkan ulang konsep materi dalam multi media sebagai bahan penguatan; dan (9) Guru dan siswa mengambil kesimpulan.

Berdasarkan permasalahan tersebut penulis berpendapat bahwa lemahnya hasil belajar pada mata pelajaran agama islam pada materi hukum bacaan qalqalah dan ra dapat disebabkan lemahnya minat dan motivasi dalam pembelajaran agama islam. Dan lemahnya minat dapat disebabkan pula oleh lemahnya strategi, alat pembelajaran yang digunakan guru.

Berdasarkan permasalahan tersebut maka peneliti melaksanakan penelitian yang berjudul "Upaya Meningkatkan Minat Belajar Agama Islam Pada Materi Hukum Bacaan Qalqalah Dan Ra. Melalui Penggunaan Model Make A Match Pada Siswa Kelas VIII.12 SMP Negeri 2 Singaraja Semester Ganjil Tahun Pelajaran $2017 / 2018$ "

\section{Metode Penelitian}

Pada penelitian ini, rancangan penelitian tindakan digunakan dengan berpedoman pada penelitian tindakan yang di desain oleh Dave Ebbut (1985) dalam Sadikin, Basori, Suranto 2002;47). Untuk lebih jelasnya desain penelitian dimaksud seperti yang disajikan pada gambar berikut. 


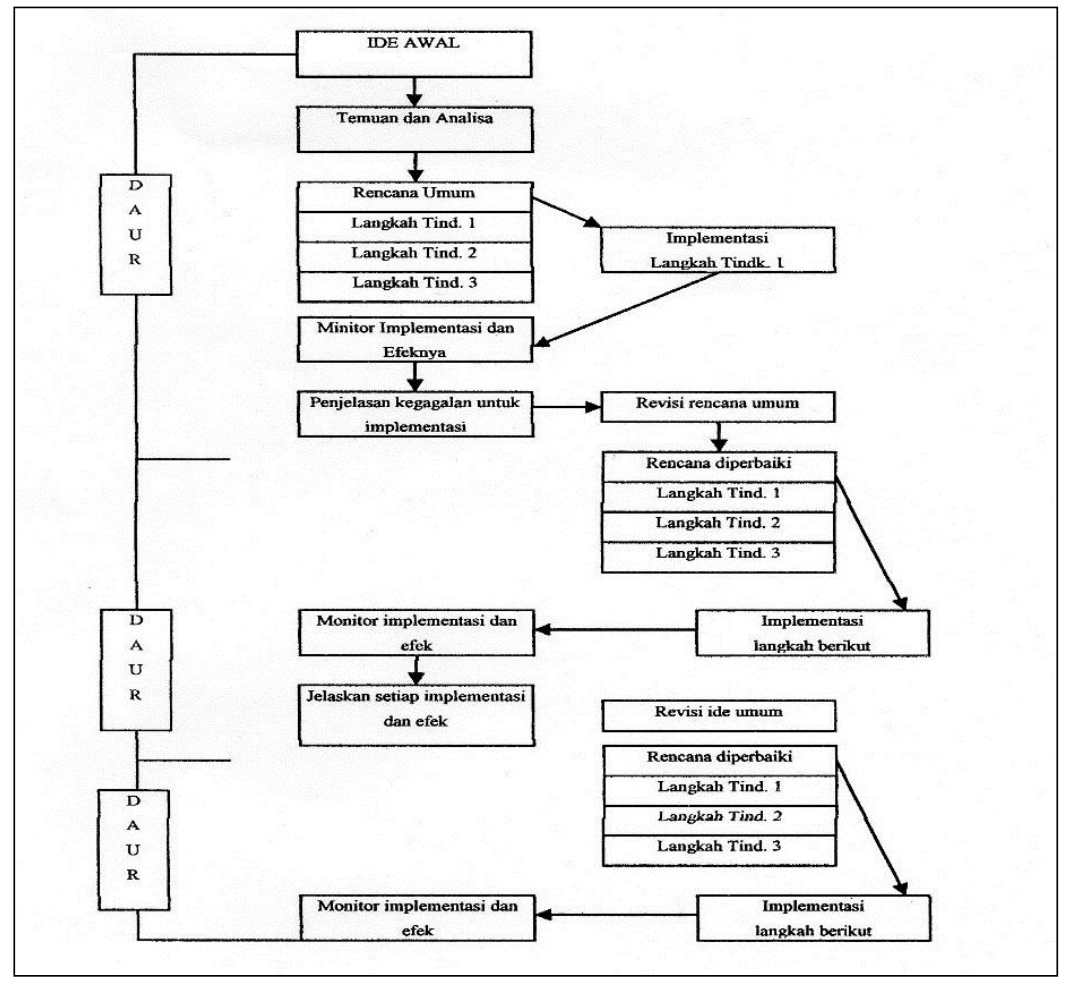

Gambar 1. Desain Penelitian Tindakan Model Dave Ebbut (1985)

Dalam rancangan tersebut terlihat bahwa penelitian tindakan diawali dengan sebuah ide, yang muncul akibat adanya sebuah permasalahan yang sangat mendesak untuk ditanggulangi. Penanggulangan permasalahan dimaksud dilaksanakan secara berdaur, dimana setiap daur dilaksanakan dengan tahapan-tahapan tindakan secara sistematis, dan setiap tindakan merupakan kelanjutan dari tindakan sebelumnya.

Penelitian ini dibatasi pada 2 (dua ) siklus saja. Masing-masing siklus terdiri dari 3 (tiga) kali pertemuan, Jika penelitian telah terlaksana dalam 2 (dua) kali siklus, maka bagaimanapun hasilnya penelitian harus dihentikan. Penelitian tindakan kelas ini dilakukan pada semester ganjil bulan Juli s.d. November, bertepat di SMPN 2 Singaraja. Dengan Subjek penelitian ini adalah Siswa Kelas VIII.12 SMP Negeri 2 Singaraja, berjumlah 11 orang. Pemilihan subyek didasarkan kepada permasalahan yang ditanggulangi dalam penelitian ini muncul pada kelas ini, dan peneliti bertugas mengajar pada kelas ini juga. Sedangkan Yang menjadi obyek penelitian ini adalah hasil belajar siswa kelas VIII.12 Negeri 2 Singaraja, setelah penerapan Model Pembelajaran make a macth dalam pembelajaran secara konsisten.

Prosedur penelitian sangat tergantung dari model penelitian tindakan yang diterapkan. Model penelitian tindakan yang dilaksanakan adalah model Suharsimi Arikunto, Suhardjono, Supardi (2006: 74). Dengan demikian maka prosedur pelaksanaan tindakan setiap siklusnya secara berdaur meliputi Langkah-langkah: 1) Rancangan awal, sebelum mengadakan penelitian peneliti menyusun rumusan masalah, tujuan, membuat rencana tindakan, dan perangkat pembelajaran; 2) Tindakan dan observasi, meliputi tindakan yang dilakukan peneliti sebagai upaya membangun pemahaman konsep peserta didik serta mengamati hasil atau dampak dari diterapkannya penerapan model make a match dan multimedia; 3) Refleksi, peneliti mengkaji, melihat dan mempertimbangkan hasil atau dampak dari tindakan yang dilakukan berdasarkan lembar pengamatan yang diisi oleh pengamat/kolabolator. 4) Rancangan/rencana yang direvisi, berdasarkan hasil refleksi dari pengamat membuat rancangan yang direvisi untuk dilaksanakan pada siklus berikutnya.

Dalam penelitian tindakan kelas ini data dikumpukan dengan cara observasi, wawancara dan post-tes. Serta instrument yang digunakan adalah panduan observasi digunakan untuk mengetahui tindakan belajar peserta didik, aktivitas peserta didik dalam mencari pasangan dan pengamatan terhadap guru yang mengajar dan soal-soal digunakan untuk mengamati peningkatan penguasaan konsep dan penerapan contoh-contoh bacaan yang mengandung hukum bacaan qalqalah dan ra.

Penelitian ini menggunakan analisis diskriptif, berdasarkan data-data yang dukumpulkan. 1) Hasil belajar dianalisis dengan analisis deskriptif yaitu membandingkan hasil belajar (nilai tes) antar siklus, Hasil tes juga dianalisis untuk mengetahui persentase siswa yang mencapai batas ketuntasan/Kriteria Ketuntasan Minimal (KKM). Pedoman kovensi hasil belajar agama islam ditunjukkan pada tabel 01. 
Tabel 1. Pedoman Konversi hasil belajar agama islam

\begin{tabular}{ll}
\hline Persentase (\%) & Kriteria \\
\hline $90-100$ & Sangat Baik \\
$75-89$ & Baik \\
$65-74$ & Cukup \\
$40-64$ & Kurang \\
$0-39$ & Sangat Kurang \\
\hline
\end{tabular}

Observasi atau pengamatan dilakukan untuk mengetahui perkembangan kemampuan peserta didik. Yang diamati antara lain :1) Jalannya proses pembelajaran 2) Situasi lingkungan dan subjek penelitian pada waktu proses pembelajaran, dan 3) Tingkah laku siswa selama proses pembelajaran berlangsung.

\section{Hasil dan Pembahasan}

Sebagai gambaran kondisi awal peserta didik di SMP Negeri 2 Singaraja kelas kelas VIII.12 sebelum dilakukannnya penerapan model make a match dari hasil observasi dan informasi dari guru serta wawancara dengan sebagian siswa keadaannya sebagai berikut : 1) Hasil observasi antara lain: (a) siswa sulit masuk ke dalam kelas, (b) sengaja tidak masuk (membolos) ke ruangan Agama Islam, (c) apabila di dalam kelas atau ruangan Agama Islam peserta didik tidak serius untuk mengikuti pelajaran Agama Islam, ketika sedang belajar ngobrol dengan suara keras, dan (d) Peserta didik terbiasa melaksankan tugas sendiri dengan mencatat di dalam kelas dikarenakan tidak memiliki buku paket. 2) Hasil wawancara Sebelum tindakan dilaksanakan penulis mengajukan beberapa pertanyaan kepada para peserta didik tentang malasnya siswa masuk ke ruangan Agama Islam ( ruang OSIS ). Dari jawaban anak di antaranya mereka menjawab beberapa hal, diantaranya : (1) tidak bersemangat (2) tidak menarik (3) monoton (4) mencatat terus.

Dengan data yang ada di atas, maka peneliti mengambil simpulan bahwa terdapat sebagian besar peserta didik tidak memiliki minat belajar Agama Islam, tidak berani merespon tentang materi hukum bacaan qalqalah dan ra.

Sebagai guru pada minggu ke dua penulis melakukan pra tindakan Kelas. Hasil pengamatan menunjukkan adanya respon yang kuat untuk belajar. Ini terlihat dari perhatian cukup besar. Peseta didik jadi diam, mau mencatat juga mendengarkan penjelasan-penjelasn guru. Namun kegiatan siswa terbatas hanya diam, melihat mencatat dan sesekali bertanya, tidak adanya keterlibatan siswa secara motorik dan komunikasi antar siswa dalam belajar.

\section{Tindakan Kelas Siklus I}

Pada siklus I ini perencanaan tindakan kelas yang peneliti lakukan adalah :1) Menentukan Pokok bahasan yaitu, standar kompetensi Al-Quran materi hukum bacaan qalqalah dan ra; 2) Membuat rencana pelaksanaan pembelajaran (RPP) yang telah disiapkan untuk PTK penerapan model make a macth: 3) Membuat format wawancara; 4) Membuat lembar observasi; dan 5) Membuat alat evaluasi (post-tes).

Dalam pelaksanaan tindakan yang peneliti lakukan adalah sebagai berikut: 1) Sebelum pembelajaran dimulai peneliti terlebih dulu melakukan setting kelas dengan posisi duduk biasa; 2) Memberi informasi secara singkat tujuan pembelajaran dari kompetensi dasar menjelaskan pengertian hukum bacaan qalqalah dan penerapannya dalam al-Quran; Mengadakan pre-tes pada awal siklus untuk mengetahui kondisi awal peserta didik sebelum diberi tindakan/ treatment; 3) Guru menginformasikan tentang tujuan pembelajaran dan materi pelajaran yang akan dipelajari kepada peserta didik; 4) Guru menjelaskan secara singkat tentang model make a macth dengan berbagai variasi metode penyajian, juga variasi isi peresentasi yang terdiri dari: teks, animasi, lagu, dan photo/gambar agar memberi sugesti pada peserta didik agar mampu meningkatkan minat pada materi hukum bacaan qalqalah dan ra; 5) Guru membagikan potongan-potongan kertas (ukuran kartu pos) kepada peserta didik secara acak yang telah diisi dengan jenis qalqalah pada satu kartu dan contoh bacaan yang mengandung hukum qalqalah dan ra; 6) Setelah semua peserta didik mendapatkan kartu, kemudian mereka membaca serta mengangkat kartu itu tinggi-tinggi agar diketahui teman yang lainnya; 7) Pada saat teman lainnya bertanya mereka saling memperlihatkan kartu, kalau tidak cocok, mereka mencari ulang sampai berhasil. Waktu untuk mencocokkan tidak lebih dari 5 menit, setelah 5 menit semua peserta didik berhenti mencari pasangan; 8) Setelah selesai mereka mendapat pasangan, mereka kemudian memisahkan diri dari teman yang lain berpasangan. Adapun yang merasa tidak menemukan berpasangan dalam waktu yang ditentukan mereka berkumpul pada tempat terpisah; 9) Setiap pasangan peserta didik mempresentasikan hasil temuannya yang dicocokkan dalam media yang tersedia. Peserta yang sudah berhasil mempresentaskan diberikan tepuk tangan oleh teman yang lainnya. 10) Setiap pasangan atau peserta diberi kesempatan untuk menanggapi hasil temuan peserta yang lain. Kesempatan menjawab diberikan kepada peserta didik; 11) Peserta didik mengambil kesimpulan tentang hukum bacaan qalqalah dan ra. 12) Guru menyimpulkan dan merangkum dari beberapa hasil 
pasangan dan presentasi peserta didik dengan memperlihatkan ulang materi yang tersedia 13) Melakukan refleksi di akhir pertemuan agar peserta didik merasa banwa hari ini mereka belajar sesuatu yang sangat berguna bagi hidupnnya. 14) Meminta peserta didik untuk membiasakan membaca al-Quran dengan mengikuti aturan tajwid yang berlaku.

Berikut ini pandangan umum pengamatan terhadap tindakan pada siklus I dalam menggunakan model pembelajaran Make a macth dalam pembelajaran materi hukum bacaan qalqalah dan ra : 1) Partisipasi dan keterlibatan peserta didik dalam menerapkan model make a macth. pada siklus I ini masih terasa canggung, hal ini dikarenakan peserta didik selama ini belum pernah melakukan, baik pada mata pelajaran Pendidikan Agama Islam maupun mata pelajaran yang lain; 2) Akan tetapi sikap canggung yang dialami peserta didik tidak berjalan lama, setelah berjalan beberapa saat maka peserta didik terlihat sudah bisa menyesuaikan diri dengan strategi yang dilakukan. 3) Saat pemberian pemahaman konsep, peserta didik duduk dan menyimak karena para peserta didik harus melihat tayangan materi qalaqlah, sebagai persiapan mengikuti mencari pasangan. Kemudian guru memberi aba-aba, peserta didik menjadi sibuk mencari pasangan satu-persatu. Suasana kelas saat diterapkannnya model make a macth menjadi ramai, karena para peserta didik harus mencari pasangan kartunya; 4) Aktifitas peserta didik saat mencari pasangan aktifitas peserta didik saat mencari pasangan pada siklus I ini tergolong masih dalam tingkatan sedang, terlihat sebagian peserta didik masih tampak ragu-ragu; 5) Aktifitas mempresentasikan kartu kemauan dan kemampuan menyampaikan hasil temuan masih merasa canggung, sebab mereka harus menyebutkan nama soal dan jawabannya termasuk membacakan kalimat yang mengandung hukum bacaan qalqalah dan ra.

Gejala-gejala positif maupun negatif yang muncul pada saat tinda Kan dilakukan adalah : a) Peserta didik sangat antusias; b) Peserta didik tampak merasa senang mencari pasangan.

Sedangkan gejala-gejala negatif yang muncul pada saat tindakan adalah : a) Ada peserta didik yang kurang peduli memperlihatkan kartunya pada teman yang sedang mencari pasangan sehingga yang bersangkutan tidak dapat menemukan pasangannya sesuai waktu yang ditentukan; b) Peserta didik masih tampak gaduh bertanya dan diskusi tentang pasangan kartu yang sedang disesuaikan.

Berdasarkan hasil pengamatan dua guru pengamat (observers) terhadap perencanaan penggunaan model pembelajaran make a match dalam proses pembelajaran Agama Islam, maka dapat dinyatakan bahwa, hasil Penilaian pre test dan post penerapan model Make a macth pada materi hukum bacaan qalqlah adalah seperti tercantum dalam tabel 02 dibawah ini.

Tabel 2. Rekapitulasi nilai hasil belajar peserta didik siklus I

\begin{tabular}{llcccl}
\hline \multirow{2}{*}{ No } & Nama & Nilai Tes & & & Ketun \\
\cline { 2 - 5 } & Pre-tes & $\begin{array}{c}\text { Post- } \\
\text { test }\end{array}$ & Peningkatan & Tasan \\
\hline $\mathbf{1}$ & Agung Panji Supriyanto & 25 & 60 & 40 & Tidak Tuntas \\
2 & Anddera Ferrisa Adz-Ziky & 20 & 70 & 55 & Tidak Tuntas \\
3 & Anis Arista & 30 & 80 & 65 & Tuntas \\
4 & Echa Putri Ramadhani & 20 & 70 & 40 & Tidak Tuntas \\
5 & Firman Wahyudi S & 25 & 70 & 35 & Tidak Tuntas \\
6 & Haykal Bintang Arizona & 35 & 90 & 55 & Tuntas \\
7 & July Handayani & 25 & 50 & 35 & Tidak Tuntas \\
8 & Muhammad Naufal S & 25 & 80 & 50 & Tuntas \\
9 & Nuklia Melati Puspita N & 55 & 70 & 20 & Tidak Tuntas \\
10 & Wahyu Candra Maya & 35 & 70 & 25 & Tidak Tuntas \\
11 & Axel Aryaduta Siagian & 35 & 70 & 35 & Tidak Tuntas \\
\hline
\end{tabular}

Keterangan :

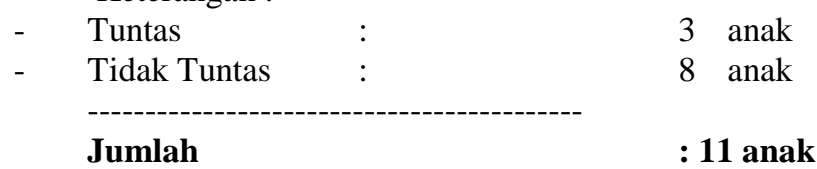

Pada siklus I setelah pemanfaatan model pembelajara make a match ternyata terjadi kenaikan hasil belajar yang ditandai dengan rata-rata 75,83 dan ketuntasan belajar 65,79\%. Dari analisis data hasil belajar melalui pree test dan post tes hasilnya sangat tinggi. Hal Ini terlihat dari nilai rata-rata pree tes dan post yang jauh berbeda. Hal ini pula yang mengantarkan tuntasnya belajar para peserta didik.

Dari hasil pengamatan yang peneliti lakukan maka yang perlu mendapat perhatian dan perbaikan pada siklus berikutnya di antaranya adalah :1) Pemberian materi hukum bacaan qalqalah melalui multi media perlu diubah, yang semla memberikan pemahaman konsep dahulu, kemudian contoh-contoh. Pada Sikluske dua sebaiknya pemahaman konsep diberikan setelah diperlihatkan contoh-contoh bacaan dari ayat al-Quran yang 
ditayangkan,kemudian yang diikuti pula dengan cara membaca qalqalah. 2) Membuat suasana kelas lebih kondusif dengan tetap mengacu aba-aba dari guru pada saat mencari pasangan. 3) Waktu untuk membaca materi yang 10 menit terlalu cepat, sehingga ketika mencari pasangan ada sebagian anak yang masih sempat mencari konsep dari buku. 4) Pemberian materi yang bersifat verbalisme dikurangi, tapi lebih fokus ke pemahaman dan penerapannya. 5) Waktu untuk mencari pasangan selama 5 menit terlalu cepat, sehingga adakalanya peserta didik belum menyelesaikan tuganya, maka waktunya di tambah 7 s.d. 10 menit. Dan 6) Kemampuan anak tentang penerapan qalqlah pada al-Quran kurang dilatih, oleh karena itu perlu setting harus diperhatikan, sehingga anak diberi kesempatan lebih lama dalam menerapkan qalqlah pada al-Quran.

\section{Tindakan Kelas Siklus II}

Memperhatikan hasil pengamatan tindakan pada siklus I serta refleksi yang diberikan pengamat, peneliti melakukan langkah-langkah perbaikan, sebagai rencana untuk melangkah ke siklus II dalam penelitian ini. Pada siklus ini materi pembelajaran yang disampaikan adalah hukum bacaan Ra dan penerapannya pada al-Quran.

Beberapa rencana pada siklus II antara lain :1) Menentukan Pokok bahasan yaitu, standar kompetensi AlQuran materi hukum bacaan qalqalah dan ra. 2) Membuat rencana pelaksanaan pembelajaran (RPP) yang telah disiapkan sebagai perubahan untuk PTK siklus II dengan dietarpakan model make a macth. 3) Membuat format observasi pembelajaran. 4) Membuat lembar observasi. Dan 5) Membuat alat evaluasi (soal pre-tes dan post-tes ), bukan sekedar tes berbentuk pilihan ganda melainkan ada soal praktek mencari hukum bacaan qalqalah dan ra dari potongan ayat yang telah disiapkan.

Dalam pelaksanaan tindakan yang peneliti lakukan adalah sebagai berikut : 1) Sebelum pembelajaran dimulai peneliti terlebih dulu melakukan setting kelas yang semula posisi duduk biasa, sekarang dibuat hurup U. 2) Memberi informasi secara singkat tujuan pembelajaran dari Kompetensi dasar menjelaskan pengertian hukum bacaan qalqalah dan ra dan penerapannya dalam al-Quran. 3) Mengadakan pre-tes untuk mengetahui kondisi awal peserta didik sebelum diberi tindakan/Treatment. Guru menjelaskan secara singkat tentang model make a macth. 4) Siswa langsung dibagi 2 kelompok besar. (kelompok pertama pemegang kartu konsep hukum bacaan ra dan kelompok lainnya pemegang contoh-contoh bacaan ra). Selanjutnya Guru membagikan potonganpotongan kertas (ukuran kartu pos) kepada peserta didik menurut kelompoknya. 5) Setelah 2 kelompok peserta didik mendapatkan kartu, kemudian mereka membaca serta mengangkat kartu itu tinggi-tinggi agar diketahui teman yang lainnya. 6) Pada saat teman lainnya bertanya mereka saling memperlihatkan kartu, kalau tidak cocok, mereka mencari ulang sampai berhasil. Waktu untuk mencocokkan tidak lebih dari 10 menit, setelah waktu habis semua peserta didik berhenti mencari pasangan. 7) Setelah selesai mereka mendapat pasangan, mereka kemudian memisahkan diri dari teman yang lain berpasangan. Adapun yang merasa tidak menemukan berpasangan dalam waktu yang ditentukan mereka berkumpul pada tempat terpisah. 8) Setiap pasangan peserta didik mempresentasikan hasil temuannya yang dicocokkan dalam media yang tersedia. Peserta yang sudah berhasil mempresentaskan diberikan tepuk tangan oleh teman yang lainnya. 9) Setiap pasangan atau peserta diberi kesempatan untuk menanggapi hasil temuan peserta yang lain. Kesempatan menjawab diberikan kepada peserta didik. 10) Siswa mengambil kesimpulan tentang hukum bacaan qalqalah dan ra. 11) Guru menyimpulkan dan merangkum dari berberapa jawaban peserta didik dengan memperlihatkan ulang materi yang tersedia. Melakukan post test selain dengan memberikan soal Pilihan Ganda, siswa diberikan soal untuk mencari contoh-contoh bacaan Al-Quran yang mengandung hukum bacaan qalqalah dan ra dari kertas kerja yang telah disiapkan. 12) Melakukan refleksi di akhir pertemuan agar peserta didik merasa banwa hari ini mereka belajar sesuatu yang sangat berguna bagi hidupnnya. Dan 14) Meminta peserta didik untuk membiasakan membaca alQuran dengan mengikuti aturan tajwid yang berlaku.

Beberapa hasil dari pengamat selama proses pembelajaran yang berlangsung, di antaranya: 1) Partisipasi dan keterlibatan peserta didik dalam menerapkan penerapan model make a macth. 2) Partisipasi dan keterlibatan peserta didik dalam penerapan model make a macth pada siklus II ini terlihat lebih luwes dari pada siklus I. 3) Saat pemberian contoh-contoh dulu kemudian pada pemahaman konsep, peserta didik duduk dan menyimak tayangan materi hokum bacaan qalqalah dan ra, sebagai persiapan mengikuti mencari pasangan. Kemudian guru memberi aba-aba, peserta didik menjadi sibuk mencari pasangan satu-persatu. Suasana kelas saat diterapkannnya model make a macth menjadi ramai, karena para peserta didik harus mencari pasangan kartunya. 4) Aktifitas peserta didik saat mencari pasangan. 5) Aktifitas peserta didik saat mencari pasangan pada siklus II ini aktif, dan dalam hitungan 5 menit para peserta didik telah menyelesaikan tugasnya. 6) Aktifitas mempresentasikan kartu. Kemauan dan kemampuan menyampaikan hasil temuan sudah lancar, Namun ketika membacakan contoh-contoh bacaan hukum bacaan qalqalah dan ra yang benar masih terdapat peserta didik yang belum pas cara membacanya.

Gejala-gejala positif maupun negatif yang muncul pada saat tindakan adalah: a) Peserta didik sangat antusias. b) Peserta didik tampak merasa senang mencari pasangan. Sedangkan gejala-gejala negatif yang muncul pada saat tindakan adalah : a) Masih ada peserta didik yang kurang peduli memperlihatkan kartunya pada teman yang sedang mencari pasangan. Namun akhirnya siswa segera menemukan pasangannya, karena 
pengalaman pada siklus I. dan b) Peserta didik masih tampak gaduh bertanya dan diskusi tentang pasangan kartu yang sedang disesuaikan.

Adapun Hasil Penilaian pre test dan post penerapan model Make a macth pada materi hukum bacaan qalqlah dan ra adalah seperti tercantum dalam tabel berikut :

Tabel 3. Rekapitulasi nilai hasil belajar peserta didik siklus II

\begin{tabular}{clccc}
\hline \multicolumn{1}{c}{ Nama } & Pre-tes & $\begin{array}{c}\text { Nilai tes } \\
\text { Pos-test }\end{array}$ & Peningkatan \\
\hline 1 & Agung Panji Supriyanto & 20 & 100 & 80 \\
2 & Anddera Ferrisa Adz-Ziky & 55 & 90 & 45 \\
3 & Anis Arista & 25 & 100 & 75 \\
4 & Echa Putri Ramadhani & 35 & 100 & 65 \\
5 & Firman Wahyudi S & 40 & 90 & 50 \\
6 & Haykal Bintang Arizona & 48 & 100 & 52 \\
7 & July Handayani & 20 & 90 & 70 \\
8 & Muhammad Naufal S & 37 & 100 & 63 \\
9 & Nuklia Melati Puspita N & 20 & 100 & 80 \\
10 & Wahyu Candra Maya & 37 & 90 & 53 \\
11 & Axel Aryaduta Siagian & 55 & 90 & 45 \\
\hline Rata-rata & $\mathbf{3 9}$ & $\mathbf{8 6}$ & \\
Nilai Tertinggi & $\mathbf{6 0}$ & $\mathbf{1 0 0}$ & $\mathbf{7 5}$ \\
Nilai Terendah & $\mathbf{2 0}$ & $\mathbf{8 6} \%$ & \\
Ketuntasan Klasikal & $\mathbf{0 \%}$ & & \\
\hline
\end{tabular}

Tabel di atas menunjukkan beberapa penemuan hasil belajar siswa, sebagai berikut:1) Rata-rata hasil belajar siswa pada Siklus I dengan pre test diperoleh rata-rata 39 menunjukkan katagori yang Sangat Kurang, namun setelah diadakan post test diperoleh rata-rata 86 menunjukkan katagori yang Baik. Ini menunjukkan adanya peningkatan yang signifikan sebesar rata-ra 47. Dan 2) Ketuntasan belajar secara klasikal bila dibandingkan dengan pra siklus juga meningkat. Pada hasil pretest ketuntasannya sebesar 0\%, sedangkan pada siklus II sebesar $86 \%$, lonjakan interval angka sebesar $86 \%$ merupakan angka yang cukup besar. Hal ini juga mengindikasikan bahwa terdapat peningkatan hasil belajar secara klasikal sebelum tindakan dan sesudah tindakan.

Dari hasil pengamatan yang peneliti lakukan siklus I dan II maka hasil anlisa pelaksanaannya adalah sebagai beikut : 1) Pada siklus I peserta didik semula masih merasa canggung terhadap penerapan strategi penerapan model make a macth. Pada siklus II perasaan canggung tersebut mulai hilang. 2) Hasil yang diperoleh dari data yang terkumpul membuktikan bahwa tingkat keaktifan, nilai kogninif dan afektif dari siklus I dan II rata-rata mengalami kenaikan, dan berada di atas indikator keberhasilan yang ditetapkan. 3) Dari hasil pos tes baik hasil yang sesuai dengan skala nilai yang ditetapkan, akan tetapi masih terdapat 1 orang pada katogori kurang.

Peningkatan aktifitas pembelajaran secara optimal dalam penerapaan penerapan model make a macth dapat diketahui melalui peningkatan kemampuan peserta didik dalam menjawab soal-soal. Soal-soal diberikan pada setiap awal pertemuan sebagai pre test dan akhir pertemuan sebagai post tes. terlihat dari adanya peningkatan nilai rata-rata hasil belajar dari data awal, siklus I dan siklus II. Dari data awal rata-rata hasil belajar siswa hanya 69,69 dengan jumlah siswa yang tuntas sebanyak 39,47 \%, Pada siklus I setelah pemanfaatan model pembelajara make a match ternyata terjadi kenaikan hasil belajar yang ditandai dengan rata-rata 75,83 dan ketuntasan belajar 65,79 \%. Setelah memperbaiki kekurangan-kekurangan yang masih terjadi pada siklus I, maka pada siklus II memperoleh data hasil belajar yang meningkat secara signifikan, dalam bentuk rata-rata hasil belajar 82,70 daya serap dan ketuntasan belajar 89,47 \% .

Terjadinya peningkatan hasil belajar dari data awal sampai Siklus II, karena penerapan Model make a match dengan penerapan model pembelajaran yang dilakukan lebih menarik dan mengngurangi rasa bosan peserta didik. selain itu juga peserta didik tidak merasa kesepian dalam proses pembelajaran karena meraka mengerjakan tugas dan belajar bersama pasangannya.

Dengan kata lain keberhasilan proses pembelajarn ini berhasil tidak terlepas dari asumsi dari model make a match. Pemilihan model make a macth sebagai bagian dari cooperative learning ini didasarkan atas asumsi bahwa : 1) Sinergi yang ditingkatkan dalam bentuk kerjasama akan meningkatkan motivasi yang jauh lebih besar dari pada lingkungan kompetitif individu. 2) Anggota kelompok kooperatif dapat saling belajar satu sama lain. 3) Interaksi antar anggota akan menghasilkan asfek kognitif. 4) Kerjasama meningkatkan perasaan positif terhadap satu sama lain, membangun sebuah hubungan, memberikan pandangan positif mengenai orang lain. 5) Kerjasama meningkatkan penghargaan diri melalui perasaan dihormati dan dihargai orang lain. 6) Peserta didik yang terlibat langsung dalam proses kerjasama dapat meningkatkan kafasitasnya untuk bekerjasama secara 
produktif. Serta 7) Peserta didik bisa belajar dari beberapa latihan untuk meningkatkan kemampuan mereka dalam bekerjasama.

Dengan asumsi-asumsi tersebutlah model make a Match ini membuat siswa lebih aktif dan lebih percaya diri dalam proses pembelajaran. Guru disini hanya sebagai fasilitaor yang mendampingi siswa belajar tanpa memaksa siswa untuk menerima pengetahuan yang dimiliki oleh guru tersebut.

\section{Simpulan}

Berdasarkan paparan hasil dan pembahasan yang telah disajikan pada bagian sebelumnya dapat dikatakan bahwa terjadi peningkatan hasil belajar dari data awal, siklus I dan sisklus II. Hal ini tanpak dari data awal ratarata hasil belajar siswa hanya 69,69 dengan jumlah siswa yang tuntas sebanyak $39,47 \%$, Pada siklus I setelah pemanfaatan model pembelajara make a match ternyata terjadi kenaikan hasil belajar yang ditandai dengan ratarata 75,83 dan ketuntasan belajar 65,79 \%. Serta setelah memperbaiki kekurangan-kekurangan yang masih terjadi pada siklus I, maka pada siklus II memperoleh data hasil belajar yang meningkat secara signifikan, dalam bentuk rata-rata hasil belajar 82,70 daya serap dan ketuntasan belajar 89,47 \%.

Berdasarkan isimpulkan dari hasil penelitian, dalam upaya mencapai tujuan penelitian menjadi dasar disampaikannya saran-saran sebagai berikut: 1) Bagi guru; apabila mengalami permasalahan yang sama dengan permasalahan yang sedang ditanggulangi maka implementasi model pembelajaran ini merupakan alternatif pemecahannya, mengingat model ini telah terbukti dapat meningkatkan kerjasama, bertindak aktif, bertukar informasi, mengeluarkan pendapat, bertanya, berargumentasi dan lain-lain. 2) Bagi peneliti: walaupun penelitian ini sudah dapat membuktikan efek utama dari pemanfaatan model pembelajara make a match dalam meningkatkan hasil belajar, sudah pasti dalam penelitian ini masih ada hal-hal yang belum sempurna dilakukan, oleh karenanya kepada peneliti lain yang berminat meneliti topik yang sama untuk meneliti bagian-bagian yang tidak sempat diteliti. Guru hendaknya memahami karakter peserta didik secara keseluruhan. 3) Bagi pemerhati pendidikan: agar selanjutnya melaksanakan penguatan-penguatan, terutama memfasilitasi kegiatan-kegiatan yang bersifat inovatif sehingga penjaminan mutu pendidikan dapat berlangsung secara konsisten dan berkesinambungan.

\section{Daftar Pustaka}

Arikunto, Suharsimi; Suhardjono; Supardi. 2006. Penelitian Tindakan Kelas. Jakarta: PT Bumi Aksara. Daryanto. 1999. Evaluasi Pendidikan. Rineka Cipta: Jakarta.

Depdiknas, 2003c. Sistem Penilaian Kelas SD, SMP, SMA dan SMK. Dirjen Dikdasmen Tendik.

Depdiknas. 2011. Membimbing Guru dalam Penelitian Tindakan Kelas. Jakarta: Pusat Pengembangan Tenaga Kependidikan Badan Pengembangan Sumber Daya Manusia Pendidikan dan Menjaminan Mutu Pendidikan.

Peraturan Menteri Pendidikan Nasional No. 41 Tahun 2007 Tanggal 23 November 2007. Jakarta: Depdiknas.

Sukidin, Basrowi, Suranto. 2002. Menajemen Penelitian Tindakan Kelas. Penerbti: Insan Cendekia ISBN: 979 9048334.

Syaodih Sukmadinata, Nana. 2007. Metode Penelitian Pendidikan, Bandung: Remaja Rosda Karya.

Suhardjono. 2010. Pertanyaan dan Jawaban di Sekitar Penelitian Tindakan Kelas dan Penelitian Tindakan Sekolah. Malang: Cakrawala Indonesia 